VOX PATRUM $25(2005)$ t. 48

Beata PAWŁOWSKA

(Rzeszów, UR)

\title{
RELIGIJNE PODRÓŻE DO RZYMU W OKRESIE PRZEDKONSTANTYŃSKIM
}

W okresie przedkonstantyńskim - podróże do Rzymu trudno nazwać stricte pielgrzymkami ${ }^{1}$, bo do Wiecznego Miasta podróżowano przede wszystkim jako do stolicy Cesarstwa oraz siedziby rzymskiego biskupa. W niektórych przypadkach źródła ujawniają wprawdzie aspekt religijny tych podróży, jednak w pierwszych trzech wiekach - trzeba to wyraźnie podkreślić - chodziło raczej o spotkanie $\mathrm{z}$ chrześcijańską gminą stolicy; w żadnym, najmniejszym nawet stopniu, o peregrinatio ad loca sancta ${ }^{2}$.

Kościół rzymski korzystał od samego początku pośrednio z przywilejów, jakie wynikały $\mathrm{z}$ rangi Miasta - politycznej stolicy świata rzymskiego, kosmopolitycznego centrum, do którego prowadzily „wszystkie drogi” Cesarstwa; dla oddalonych Kościołów Europy Zachodniej, również dla Galii i dla rzymskiej Afryki, a już z całą pewnością dla całej Italii, chrześcijańska gmina w Rzymie odgrywała rolę metropolii, z którą nowe fundacje utrzymywały więzy duchowego pokrewieństwa.

${ }^{1}$ Na temat problematyki związanej z definicją „pielgrzymek” w starożytności chrześcijańskiej por. E. Wipszycka, Pielgrzymki starożytne: problem definicji $i$ cenzur, w: Peregrinationes. Pielgrzymki w kulturze dawnej Europy, red. H. Manikowska - H. Zaremska, Warszawa 1995, 17-28; tejże, Les pélerinages chrétiens dans l'antiquitè tardive. Problémes de définition et de repéres temporels, „Byzantinoslavica” 56 (1995) 429-438; R. Grégoire, Manuale di agiologia. Introduzione alla letteratura agiografica, Fabriano 1987, 353-363; P. Iwaszkiewicz, Do Ziemi Swiętej. Najstarsze opisy pielgrzymek do Ziemi Swiętej (IV-VIII w.), OŻ 13, Kraków 1996, 5-18 (przedmowa M. Starowieyskiego); B. Kötting, Peregrinatio religiosa, München 1950, 7-12; P. Maraval, Le temps du pèlerin ( $\left.V^{e}-V I I^{e}\right)$, w: Actes du Colloque: Le temps chrétien de la fin de l'Antiquitè au Moyen Âge III $-X I I I^{e}$ siècles (Paris, 9-12 III 1981), Paris 1984, 479-488.

2 Por. G. Bardy, Pèlerinage à Rome vers la fin du IV siècle, AnBol 47 (1949) 224-235; A. Hamman, Le voyage à Rome du $1^{e r}$ au $3^{e}$ siècle: raisons officielles et motifs inavoués, w: Pèlerins de Rome, ed. O. de La Brosse, Rome - Paris 1976, 27-40; W. Myszor, Ad limina Apostolorum. Podróze i pielgrzymki religijne do Rzymu $w$ starożytnym Kościele, SSHT 16 (1983) 88-91; V. Saxer, Pilgerwesen in Italien und Rom im späten Altertum und Frühmittelalter, w: Akten des XII. International Kongresses für Christlische Archäologie (Bonn 22-28 September 1991), I-II, Münster 1995, 36-57; J. Elsner - J. Rutherford, Pilgrimage in Graeco-Roman and Early Antiquity, Oxford 2006. 
Rzym był miastem ogromnym, wielojęzycznym, przyciągał do siebie najrozmaitszych ludzi. Jego żydowska gmina była liczna i wpływowa, co - jak wiadomo - odgrywało olbrzymie znaczenie w pierwszych dziesięcioleciach istnienia rzymskiego Kościoła, gdy jego związek ze społecznością żydowską był bardzo silny. Obecność Apostołów - Piotra i Pawła w początkowych latach ksztattowania się tej gminy zaważyła na dalszych jej dziejach. Dawała jej członkom pewność, że wiara przekazywana przez chrześcijańską społeczność Rzymu jest słuszna, gdyż otrzymana właśnie od tych, których autorytet nigdy nie był podważany. To ten przede wszystkim fakt pozwalał rzymskiemu Kościołowi występować w roli „strażników” prawdziwej wiary, do których można się było zwracać ze wszelkiego rodzaju wątpliwościami. Trzeba jednak zauważyć, że Miasto to nie było jedynym, mogącym się poszczycić apostolskimi początkami. Dlatego też dla pozycji Kościoła rzymskiego równie ważna zdawała się być świecka ranga Urbs Aeterna. Wydaje się, że pierwszeństwo samego Rzymu i świadomość, że Kościół rzymski przechowuje słuszną doktrynę składały się na to, co moglibyśmy nazwać honorowym prymatem tego Miasta. W praktyce jednak często nie szły za nim żelazne konsekwencje: poszczególne Kościoły radziły się co prawda biskupa Rzymu, ale w wielu przypadkach były to tylko porady, można by rzec, symboliczne: postępowały i tak zgodnie ze swą ideą czy koncepcją.

Jednym z pierwszych podróżujących do Rzymu według świadectwa Euzebiusza z Cezarei był w 1 . poł. II stulecia teolog judeochrześcijański - Hegessippos, przybyły by poznać naukę chrześcijańską i skonfrontować ją z gnostyckimi poglądami ${ }^{3}$. W tym samym czasie przebywał w Roma Aeterna i nauczał apologeta, pochodzący z Samarii, Justyn Męczennik, ,który w płaszczu filozofa głosił słowo Boże, a w swych pismach występował w obronie wiary" ${ }^{4}$. Należał on do grona wędrownych nauczycieli-filozofów: podróżował w poszukiwaniu ludzi, z którymi można było prowadzić filozoficzne dysputy ${ }^{5}$, a w Wiecznym Mieście - stolicy starożytnego świata, mógł ich znaleźć wielu.

U Euzebiusza odnajdziemy również wzmianki o tym, iż do Rzymu przybył z dalekiej Azji także biskup Smyrny - Polikarp, aby spotkać się z biskupem Anicetem (155-166) i wyjaśnić kwestie związane ze świętowaniem wielkanocnej Paschy ${ }^{6}$. W czasie swego pobytu w Rzymie, jak poświadcza Irene-

${ }^{3}$ Por. Eusebius, HE IV 11, 7, SCh 31, 175, thum. A. Lisiecki, POK 3, 158: „Za czasów Aniceta Hegessippos przybył do Rzymu i pozostal tam aż do biskupstwa Eleuterosa".

4 Por. tamże IV 11, 8.

5 Por. tamże IV 12, 11, SCh 31, 176, POK 3, 158-159: „Tenże sam Justyn wydał także doskonałe pisma, przeznaczone dla Greków, a prócz tego napisał inne dzieło, zawierające Apologię wiary naszej i ofiarował je cesarzowi Antoninowi, z przydomkiem Pobożny, oraz senatowi rzymskiemu; mieszkał bowiem w Rzymie".

${ }^{6}$ Por. tamże IV 14, 1, SCh 31, 179, POK 3, 160-161: „W owych czasach, kiedy Anicet rządził Kościołem rzymskim, żył jeszcze Polikarp, jak opowiada Ireneusz, i przebywał w Rzymie, by się ułożyć z Anicetem w pewnej spornej sprawie, dotyczącej dnia święta wielkanocnego". 
usz $^{7}$, Polikarp głosząc naukę apostolską nawrócił wielu heretyków. Najprawdopodobniej jednak chodziło nie tyle o fakt samego nawracania, ile raczej o ostrzeganie rzymskich chrześcijan przed uleganiem gnostyckim naukom.

Zauważmy, że już pod koniec II wieku, Ireneusz z Lyonu w swym traktacie Przeciwko herezjom, zwłaszcza gnostykom, zapewnia, że ci wszyscy, którzy zastanawiają się nad regułami wiary, winni udać się do Rzymu: tam bowiem zachowały się nieskażone nauki obu Apostołów, przekazywane wiernie od początku przez wszystkich ich następców, na których kolejno spoczywal ciężar przechowywania „przesłania"8. Argumentacja ta, godząc w tych, którzy utrzymują, że posiedli znajomość tajemnej tradycji, przypisywała, według autora, Rzymowi szczególny przywilej interweniowania w dysputach na temat wiary przed wszystkimi innymi Kościołami.

W swym traktacie Ireneusz wymienia kilkakrotnie gnostyków przybyłych z różnorakich stron, próbujących znaleźć właśnie w Rzymie posłuch dla swych nauk, a mianowicie: Walentyna, działającego w czasach od biskupa Hygina (136-140) aż po Aniceta (155-165) ${ }^{9}$, heretyka syryjskiego pochodzenia Cerdona, który występował w Rzymie z wyraźnie dualistycznymi poglądami ${ }^{10}$, jego „następcę” Marcjona, przybylego do Rzymu z Pontu, usiłującego przedstawić swe poglądy na synodzie w 144 r. i jeszcze w lipcu tego samego roku potępionego przez Kościół rzymski ${ }^{11}$; w lipcu tegoż roku przybyła też do Rzymu Marcelina - inna wielka zwolenniczka nauki gnostyckiej ${ }^{12}$. W Rzymie działali

${ }^{7}$ Por. Irenaeus, Adversus haereses III 3, 4, SCh 211, 40, thum. A. Bober, Antologia patrystyczna, Kraków 1965, 40: „Za Aniceta przebywał w Rzymie i wielu z wyżej wspomnianych heretyków nawrócił do Kościoła Bożego".

${ }^{8}$ Por. Adversus haereses III 3, 2, SCh 211, 32, Bober s. 39: „Ponieważ jednak wyliczenie sukcesji wszystkich Kościołów zajęłoby w niniejszym dziele zbyt wiele miejsca, przeto wskazując na następstwa największego i najstarszego i wszystkim znanego, przez dwóch najchwalebniejszych apostołów Piotra i Pawła zalożonego i ustanowionego w Rzymie Kościola, który posiada tradycje od apostolów i wiarę opowiadaną ludziom, a dochodzącą aż do nas drogą kolejnego następstwa biskupów [...]. Z tym bowiem Kościołem dla jego naczelnego zwierzchnictwa musi się zgadzać każdy Kościól, tj. wszyscy zewsząd wierni, bo w nim przez tych, co są zewsząd, zachowała się tradycja apostolska (propter potentiorem principalitatem necesse est omnem convenire Ecclesiam)".

${ }^{9}$ Por. tamze III 4, 3, SCh 211, 50, Bober s. 41: „Walentyn bowiem przybył do Rzymu za Hygina, rozwinął pełną działalność za Piusa i dożył czasów Aniceta"; zob. także Eusebius, HE IV 14, SCh 31, 179, POK 3, 161.

${ }^{10}$ Por. Irenaeus, Adversus haereses I 27, 1, FCh 8, 318-320, Bober s. 32: „Niejaki Kerdon, który wyszedł ze szkoły Szymona Czarnoksiężnika, przybył do Rzymu za Hygina (138-142) [...] i nauczał, że Bóg, którego zwiastowal Zakon i prorocy, nie jest Ojcem Pana naszego Jezusa Chrystusa".

11 Por. tamże I 27, 2, FCh 8, 318, Bober s. 32: „Następca jego Marcjon z Pontu rozwiną tę naukę, bluźniąc bezwstydnie, że Bóg obwieszczony przez Zakon i proroków, jest sprawca zła”; zob. też Eusebius, HE IV 14, 5, SCh 31, 179, POK 3, 161: „Walentyn i Markion cała rzesza umysłów przewrotnych".

12 Por. tamże I 25, 6, FCh 8, 312-314: „Unde et Marcellina, quae Romam sub Aniceto venit, cum esset humus doctrinae, mutos exterminavit; gnosticos se autem vocat". 
też w tym czasie inni wpływowi gnostycy, jak Florynus czy Blastos, którzy „oderwali się od Kościoła" "13.

W 2. poł. II wieku obserwujemy dalszy znaczny napływ chrześcijan do Rzymu z terenów małoazjatyckich. Byli wśród nich też różnego rodzaju heretycy, którzy spodziewali się tu nie tylko pozyskać nowych zwolenników, ale także zobaczyć architekturę i pomniki stolicy. Tu przybył, jak sam się przyznaje, uczeń Justyna - enkratyk Tacjan Syryjczyk, którego zainteresowały m.in. zabytki Wiecznego Miasta:

„Przebywałem wreszcie także w Rzymie i widziałem tam wiele posągów przez was zgromadzonych"14.

Tutaj też działał przybyły z Azji jego uczeń o imieniu Rodon, który według świadectwa Euzebiusza zwalczał pisemnie gnostyków, a zwłaszcza Marcjona:

„Z pochodzenia Azjata, który jak sam powiada, był w Rzymie uczniem znanego nam już Tacjana, pisał rozmaite dzieła i razem $\mathrm{z}$ nimi stawal do walki przeciwko herezji Marcjona"15.

Źródła poświadczają, że w 2. poł. II wieku do Wiecznego Miasta przybyło też wielu zwolenników i przeciwników montanizmu. I w tym przypadku, jak się wydaje, ich podróży, podobnie jak wędrownych gnostyków i filozofów, nie można przypisywać czegoś szczególnego i nadzwyczajnego. Montanizm bowiem, jako ruch nawiązujący do pierwotnych form chrześcijaństwa, popierał wędrownych apostołów i nauczycieli. Nie wydaje się więc dziwne, że szukał zwolenników również w Stolicy. Euzebiusz z Cezarei wspomina o kilku przybyłych do Rzymu wyznawcach montanizmu, choć $\mathrm{z}$ imienia wymienia tylko jednego $\mathrm{z}$ nich - Proklosa, przeciwko któremu w czasach papieża Zefiryna (189-217) występował rzymski kapłan Gajus ${ }^{16}$.

Także z Bizancjum przybył w tym czasie do Rzymu niejaki Teodor, ,wódz i ojciec tego bezbożnego odszczepieństwa, który pierwszy twierdzil, że Chrystus jest tylko człowiekiem" ${ }^{17}$. Został on przez rzymskiego biskupa Wiktora (189-198) wykluczony z Kościoła za błędy natury dogmatycznej. Inny znów przybysz z Azji - Prakseasz przybył do Rzymu ok. 180 r. „przywożąc” ze sobą herezję patrypasjanizmu. To właśnie przeciw niemu Tertulian napisał rozprawę Adversus Praxean ${ }^{18}$, w której ostro zwalczał głoszoną przez niego teorię ${ }^{19}$.

13 Por. Eusebius, HE V 15, SCh 41, 45, POK 3, 224: „Inni zaś działalność swą rozwinęli w Rzymie. Na ich czele stanął Florynus, który utracił prezbiterat kościelny, a z nim razem Blastos, który się w podobny sposób pogrążył w upadku; oderwali oni wielu od Kościoła".

14 Tatianus, Oratio ad Graecos 35, 1, PG 6, 877B, thum. L. Misiarczyk, BOK 24, 349.

15 Eusebius, HE V, 13, 1, SCh 41, 42, POK 3, 221.

16 Por. Eusebius, HE III 31, 4, SCh 31, 142, POK 3, 131; tenże, HE VI, 20, 3, SCh 41, 120, POK $3,276:$, [...] przeciwko Proklosowi, szermierzowi herezji katafrygijskiej”.

17 Tamże V 28, 6, SCh 41, 75-76, POK 3, 246.

${ }^{18}$ Por. Tertullianus, Adversus Praxean 1, CCL 2, 1159-1205, tłum. E. Buszewicz, ŻMT 4, 35-86. 
Początkiem III wieku, za papieża Kaliksta (217-222), zauważamy w Rzymie obecność niejakiego Alkibiadesa z Apamei z Syrii, który według Hipolita propagował poglądy elkazaitów, powołując się na podyktowaną mu przez anioła księgę objawień. Rzymski kapłan Hipolit wystąpił ostro przeciw niemu sugerując jednocześnie, że jego poglądy podzielał sam Kalikst ${ }^{20}$. Hipolit wymienia również i innych przybyszów do Wiecznego Miasta za czasów biskupa Kaliksta, jak: Epigonusa ze Smyrny - ucznia Noeta, który pozyskał sobie nawet w Rzymie ucznia w osobie Klemensa ${ }^{21}$, czy też Sabeliusza z Pentapolis, wykluczonego, według Hipolita, przez rzymskiego biskupa z grona wiernych ${ }^{22}$. Również w korespondencji św. Cypriana z Kartaginy $(† 258)$, spotykamy wzmiankę o schizmatyku Fortunatusie przybyłym do Rzymu „do katedry Piotra (ad Petri cathedram) i do Kościoła zajmującego pierwsze miejsce, źródła jedności kapłańskiej"23.

Obok thumnego napływu do Rzymu różnego rodzaju innowierców, do Wiecznego Miasta przybywali także ludzie związani z „prawdziwą” wiarą Kościoła. Źródła starożytne wspominają tu dwie postacie, które możemy bliżej zidentyfikować: Abercjusza - biskupa Hierapolis oraz Orygenesa. Abercjusz - chrześcijanin z Frygii, przebywał w Rzymie w tym samym czasie co Ireneusz, zmarł ok. $200 \mathrm{r}$. w wieku 72 lat $^{24}$. W swoim epitafium ${ }^{25}$ wspomina swe podróże do Rzymu, Syrii i Nisibis, za rzeką Eufrat. Do Rzymu, aby oglądać jego majestat, wysłał go, jak sam wyznaje, jego nauczyciel - „niepokalany pasterz”:

„Na imię mi Abercjusz, uczeń niepokalanego Pasterza,

Który oczy ma wielkie, dosięgające wszystkiego.

On to mię nauczył [...] Pisma niemylnego,

On też posłał mię do Rzymu, abym oglądał majestat królewski -

${ }^{19}$ Por. tamże 1, 4, CCL 2, 1159, ŹMT 4, 35: „[...] przykładem jest Prakseasz. On bowiem pierwszy przeszczepił z Azji do Rzymu ten rodzaj błędnych mniemań".

20 Por. Hippolytus, Refutatio omnium haeresium IX 13, GCS 26, 251-252.

${ }^{21}$ Por. tamze XI 7, GCS 26, 269.

22 Por. tamze IX 12, GCS 26, 246-251.

${ }^{23}$ Cyprianus Carthaginiensis, Epistula 59, 14, 1, CSEL 3C, 683, thum. W. Szołdrski, PSP 1, 188: „Post ista adhuc insuper pseudoepiscopo sibi ab haereticis constituto navigare audent et ad Petri cathedram adque ad ecclesiam principalem unde unitas sacerdotalis exorta est ab schismaticis et profanis litteras ferre nec cogitare eos esse Romanos quorum fides apostolo praedicante laudata est, ad quos perfidia habere non possit accessum". Cathedra - symbol autorytetu biskupa jako zwierzchnika lokalnej wspólnoty chrześcijan, por. B. Iwaszkiewicz-Wronikowska, Problem christianizacji starożytnych miast Zachodu w świetle badań archeologicznych, w: Miasto w starożytności, red. L. Mrozewicz - K. Balbuza, Poznań 2004, 471.

${ }^{24} \mathrm{O}$ Abercjuszu i jego epitafium por. W. Smiałek, De inscriptione Abercii supplenda, Z pielgrzymki biskupa Hierapolis do Rzymu, GK 37 (1930) 173-174 (trudno się jednak zgodzić $\mathrm{z}$ terminem "pielgrzymka” zawartym $\mathrm{w}$ artykule, a odnoszącym się do pobytu Abercjusza w Rzymie); Bober, Antologia, s. 489-491; RACh I 12-17; J. Bilczewski, Eucharystia, Kraków $1898,213-253$.

${ }^{25}$ Tekst w orginale zob. J. Quasten, Monumenta eucharistica et liturgica vetustissima, Bonn 1935, 21-24, jej przekład m.in. J. Bilczewski, w: Bober, Antologia, s. 489-451. 
I przypatrzył się Królowej, noszącej złotą szatę i złote sandały.

Widziałem nadto lud, naznaczony świetlanym znamieniem.

Dalej oglądałem równiny Syrii i wszystkie miasta, Nisibis

Poza Eufratem: wszędzie zaś znalazłem braci" ${ }^{26}$.

Napis ten potwierdzałby motyw odwiedzania Wiecznego Miasta w celu przyjrzenia się bliżej Kościołowi w stolicy i mieszkającym w niej chrześcijanom. Z kolei Orygenes przebywal w Rzymie, jak zaznacza Euzebiusz, bardzo krótko za czasów Zefiryna (prawdopodobnie w 212 r.) po to, by „oglądać prastary Rzymian Kościót" "27. Takich kontaktów z Rzymem było zapewne więcej; często przybywali tu także nieznani z imienia chrześcijanie z Afryki Północnej, co obficie poświadcza bogata korespondencja Cypriana z Kartaginy z poł. III wieku ${ }^{28}$.

Analizując źródła przedkonstantyńskie, pod kątem motywów odwiedzania Rzymu, można odnieść wrażenie, iż pierwszą kategorię stanowili heretycy, pragnący mieć większą możliwość propagowania, albo też nawet szukanie potwierdzenia swoich poglądów przez rzymskiego biskupa. W ujęciu autorów chrześcijańskich zainteresowanie heretyków pobytem w Rzymie w okresie przedkonstantyńskim, z uwagi na Kościół i biskupa rzymskiego, nie wydają się być jednak czymś niezwykłym. W pismach tych wyraźnie podkreślony został aspekt apologetyczny. Te najstarsze i często dość jednostronne informacje o podróżnikach przybyłych do Rzymu, wynikają przed wszystkim z rodzaju źródeł. Ireneusz, Euzebiusz, Tertulian czy Hipolit w swych pismach wykazywali jasno i dobitnie, że owi przybysze, mimo że pragnęli zyskać sobie poparcie biskupa Rzymu, zostali ostatecznie z Kościoła wykluczeni. Drugą kategorię natomiast stanowią podróże „zwykłych” podróżników związanych z Kościołem „prawdziwą” wiarą. Nimi to jednak polemicznie nastawieni Ojcowie Kościoła tamtych czasów nie byli zainteresowani na tyle, by ich wspominać i wyliczać imiennie $w$ swoich pismach. Uznali - być może - te ich podróże do Wiecznego Miasta za rzecz jak najzupełniej naturalną.

Sytuacja prawna Kościoła począwszy od IV wieku zmieniła się na tyle, że jeśli chodzi o podróże do Rzymu, to w większości przypadków nabierać one zaczęły coraz bardziej charakteru tylko i wyłącznie religijnego. Należy podkreślić, iż jednym z pierwszych, głównych „motorów przyciągających” (co potwierdzają też źródła z tego okresu), pozostał nadal autorytet biskupa Rzymu, jako ostateczny wyznacznik w sprawach wiary, celem rozstrzygania wszelkiego ro-

${ }^{26}$ Inscriptio Abertii 3, 6-11, thum. J. Bilczewski, w: Bober, Antologia, s. 489.

27 Eusebius, HE VI 14, 10, SCh 41, 108, POK 3, 269.

${ }^{28}$ Por. Cyprianus, Epistulae: 8, CSEL 3/2, 485-488, PSP 1, 30-33; 9, CSEL 3/2, 488-489, PSP 1 , 45-46; 20, CSEL 3/2, 572-529, PSP 1, 73-75; 21, CSEL 3/2, 529-532, PSP 1, 75-78; 22, CSEL 3/2, 533534, PSP 1, 78-80; 27, CSEL 3/2, 540-544, PSP 1, 83-86; 28, CSEL 3/2, 545-547, PSP 1, 86-88; 30 , CSEL $3 / 2,549-556$, PSP $1,89-95 ; 31$, CSEL $3 / 2,557-564$, PSP $1,95-100 ; 35$, CSEL $3 / 2,571-573$, PSP 1, 105-106; 36, CSEL 3/2, 572-575, PSP 1, 106-109; 37, CSEL 3/2, 576-579, PSP 1, 109-112; 48, CSEL $3 / 2,606-608$, PSP $1,131-133 ; 52$, CSEL 3/2, 616-620, PSP 1, 137-140. 
dzaju sporów. Ten motyw, jak się okaże, będzie nadal stale wzrastał i niejednokrotnie towarzyszył przybywającym do Wiecznego Miasta. Jednak od pol. IV wieku odnaleźć możemy jeszcze jeden bardzo istotny czynnik, który znacznie zwiększy liczbę przybywających do Rzymu i to już niekoniecznie tylko w sprawach sporów doktrynalnych: mowa tu oczywiście o wzrastającym kulcie męczenników, zwłaszcza świętych Piotra i Pawła ${ }^{29}$. Kościół rzymski, chcąc podkreślić obecność obu Apostołów, posługiwać się zaczął się językiem liturgii. Swięto obu męczenników obchodzono w tym samym - ustalonym według tradycji w 258 r. - dniu 29 czerwca $^{30}$; św. Piotra czczono dodatkowo 22 II (Natale Petri de Cathedra) ${ }^{31}$. Rozpowszechnienie wspomnienia świętych Piotra i Pawła w całym Kościele stało się z czasem jednocześnie przypomnieniem znaczenia Rzymu i stolicy jego Biskupa, następcy św. Piotra, w ówczesnym świecie. Tak więc oba czynniki zaczęły się nawzajem przenikać i uzupełniać. Relikwie Apostołów - rękojmia bezpieczeństwa i pomyślności Miasta ${ }^{32}$ - stawały się celem peregrynacji samych w sobie. Do tego dochodziło jeszcze pragnieniem uczestnictwa w rzymskiej liturgii z udziałem biskupa Rzymu, a także sprawy jak najbardziej „przyziemne”: czysto ludzka ciekawość zobaczenia wspaniałych chrześcijańskich budowli, wzniesionych $z$ inicjatywy Konstantyna, czy wreszcie chęć odwiedzenia dawnej stolicy Cesarstwa.

\section{RELIGÖSE REISEN NACH ROM IM ZEITRAUM VOR KONSTANTIN DEM GROSSEN}

\section{(Zusammenfassung)}

Im Zeitraum vor Konstantin dem Großen - ist es schwer, die Reisen nach Rom im stricten Sinne als Pilgerfahrten zu bezeichnen: denn zu dieser Zeit betrachtete man Reise in die Ewige Stadt als eine Reise zur Hauptstadt des Kaiserreichs und zum Sitz des Bischofs. In einigen Fällen berichten zwar die Quellen über religiöse Aspekten dieser Reisen, doch in den ersten drei Jahrzehnten - das man muss

29 W IV wieku Piotr i Paweł obecni są już trwale w świadomości rzymskich chrześcijan, którzy nie mają wątpliwości, iż to właśnie oni dali podstawy ich Kościołowi, por. Ch. Pietri, Roma christiana, Rome 1976, 358-361.

${ }^{30}$ Por. Depositio Martyrum: „III Kal. iul.” (MGHaa IX 71); Martyrologium Hieronymianum: „III Kal. iul." (ed. H. Delehaye, ASS Novem. II 2, 343); Pietri, Roma Christiana, s. 1539-1541.

${ }^{31}$ Por. J. Naumowicz, Natale Petri de Cathedra. Geneza święta, VoxP 24 (2004) t. 46-47, 255-264.

32 Por. Prudentius, Peristephanon XII 55-56, CSEL 61, 422, thum. M. Brożek, PSP 43, 290: "Oto nagrody dwie razem, za wierność, przez Boga złączone / Miastu Rzymowi dane, by je we czci miako". 
deutlich betonen - ging es vor allem um die Begegnung mit der christlichen Gemeinde der Hauptstadt, auf keinen Fall aber, auch nicht im geringsten Sinne um peregrinatio ad loca sancta.

Wenn man die Quellen aus den ersten drei Jahrhunderten unter dem Aspekt analisiert, welche Gründe die Menschen dazu bewegten, Rom zu besuchen, gewinnt man den Eindruck, es waren an erster Stelle Häretiker, die sich dadurch größere Verbreitungsmöglichkeiten für ihre Ansichten erhofften oder sogar Bestätigung für diese bei dem römischen Bischof suchten. In diesen Schriften wurde deutlich der apologetische Aspekt hervorgehoben. Diese ältesten und oft ziemlich einseitigen Informationen über Reisende, die nach Rom kamen, ergeben sich vor allem aus der Art der Quellen. Irenäus, Eusebius, Tertullian oder Hippolyt weisen in ihren Schriften deutlich darauf hin, dass jene Ankömmlinge, obwohl sie Unterstützung beim Bischof suchten, letztendlich aus der Kirche ausgestoßen wurden.

An zweiter Stelle stehen Reisen ,einfacher” Reisenden, die durch wahres Glauben mit der Kirche verbunden waren. Nur an dieser Art von Besuchern hatten die polemisch eingestellten Vater der damaligen Kirche wenig Interesse, um sie namentlich in eigenen Schriften zu erwähnen. Vielleicht aber betrachteten sie ihre Reisen in die ewige Stadt als etwas ganz Normales. 